Chapter 8

\title{
Differentiated Foods for Consumers with New Demands
}

\author{
Alessandra Yuri Tsuruda, \\ Marsilvio Lima de Moraes Filho, Marli Busanello, \\ Karla Bigetti Guergoletto, Tahis Regina Baú, \\ Elza louko Ida and Sandra Garcia
}

Additional information is available at the end of the chapter

http://dx.doi.org/10.5772/53166

\section{Introduction}

In recent decades, the food industry has been meeting the growing demand of consumers in search of foods that have benefits that go beyond their nutritional value, and this sector has generated billions of dollars in the global market. Lifestyle, the convenience and speed of the preparation and the modification of eating habits among the population all reflect the increasing incidence of chronic diseases caused by eating high-calorie foods and a lack of exercise.

Advances in food science knowledge have become available to demonstrate the function and mechanism of action of bioactive compounds, and they support the inclusion of ingredients and the design and development of foods that contribute to a healthy diet that is associated with a healthy lifestyle. Although functional foods should be consumed as such and not in the form of supplements or capsules, the introduction of bioactive ingredients or components into the formulation and processes of these supplements can be a tool for industry innovation and contributes to the ability to offer products with additional quality.

Traditionally, dairy products were associated with health benefits, and in part, they still have this status; thus, innovations in this area are generally associated with the use of lactic acid bacteria $(\mathrm{LAB})$ or products containing probiotic microorganisms or the addition of functional ingredients and bioactive metabolites. Various procedures, such as encapsulation, could be used to protect and maintain the viability of microorganisms in foods. There is a 
tendency towards the use of cheap and sustainable new materials with properties consistent with ingredient control release.

The concept of functional starter cultures that per se may not be probiotics but may improve product quality or result in physiological effects for the consumer is a possibility that should be explored. In addition to the probiotic properties, other choices include the use of in situ cultures that inhibit pathogenic contaminants by antimicrobial action; degrade or remove toxic compounds; produce vitamins or exopolysaccharides (EPSs); contribute to viscosity, body or texture; and facilitate adherence to specific sites in the host.

The action of binding EPS mucoid bacteria to the protein matrix results in increased viscous behaviour, and some EPSs produced by LAB are beneficial to health due to their prebiotic and hypocholesterolemic effects, immunomodulation ability or anticancer activity. Confirming these observations, some authors reported that the production of exopolysaccharides by certain bifidobacteria can increase the viscosity of fermented foods, contributing to the rheological properties, and therefore can be considered to be natural additives preferred by consumers that can replace plant or animal stabilisers.

The use of the special characteristics of LAB to potentiate their effects in foods or food supplies to vegetarians and people with dietary or religious restrictions provides an alternative to differentiated products. This category includes foods that are lactose free, have an increased fibre content, are free of animal products, and have an increased amount of antioxidant bioactive compounds (e.g., isoflavones, aglycones, oligosaccharides). Fruits and vegetables contain high levels of beneficial substances (e.g., antioxidants, vitamins, fibre and minerals), and the addition of LAB and probiotics can add more features. The knowledge of their behaviour in fruit and vegetable matrices as vehicles for the use of probiotics or bioactive ingredients is fundamental and still largely unexplored in the literature or in industrial processes.

There is, however, a need for the emerging pressure or process as a whole to be consistent with sustainable practices throughout the production chain in terms of the economic, environmental or social issues. Each step of the process that adds value to a product or avoids the generation of waste or effluent will be in agreement with the goals of clean production.

This chapter will focus on the recovery of by-products and innovative uses of plant materials and the strengthening of the resources for and beneficial effects of combining foods to obtain value-added functional products and offer alternatives to consumers searching for ways to improve their health through specialty foods.

\section{Antioxidants from plant sources}

In recent years, natural compounds have generated great interest due to the correlation between carcinogenic effects and the ingestion of synthetic compounds. Natural compounds such as phenolics, carotenoids and organic acids are widely found in plants and vegetables 
and have been the target of numerous studies because they exhibit strong antioxidant activity in addition to the ability to reduce the incidence of cancer in humans [1-4].

There is an equilibrium between the antioxidant defence system and the pro-oxidants in the human body, which are mainly reactive oxygen species (ROS) and reactive nitrogen species (RNS). The majority of reactive species (RS) originate in endogenous metabolic processes, whereas exogenous sources may include excess iron or copper in the diet, smoking, exposure to environmental pollutants, inflammation, bacterial infections, radiation, prolonged emotional stress and unbalanced intestinal microflora. The abnormal formation of RS may occur in vivo and cause damage to lipids, proteins, nucleic acids or carbohydrates in cells or tissues, and an imbalance with regard to pro-oxidants gives rise to oxidative stress (OS) [5].

Antioxidants impede or delay the in vivo oxidation reactions of lipids and other molecules or foods, inhibiting or retarding the chain propagation of free radicals generated by oxidation, such as hydroxyl radicals $(\bullet \mathrm{OH})$. In general, antioxidants are aromatic compounds that possess at least one free hydroxyl; they may be synthetic, such as BHA (butylhydroxyanisole), or natural, such as terpenes and phenolic compounds [2, 6-9].

Many studies have demonstrated that the consumption of antioxidants in food reduces the effects of the oxidative processes that naturally occur within the organism, aiding the natural endogenous protection mechanisms, such as the activities of superoxide dismutase, catalase and peroxidase, which together with vitamins E, C and A; enzymes; and other antioxidants and reduced glutathione (GSH) constitute the integrated antioxidant defence system (IADS) of the human body [4, 5, 7-8].

Flavonoids belong to the polyphenol group, which can be further divided into 11 smaller classes, including isoflavones, anthocyanins, flavans and flavanones. Their basic structure (Figure 1) comprises a flavone nucleus with 2 benzene rings ( $\mathrm{A}$ and $\mathrm{B}$ ) bonded to a heterocyclic pyran ring (C) [10,11].

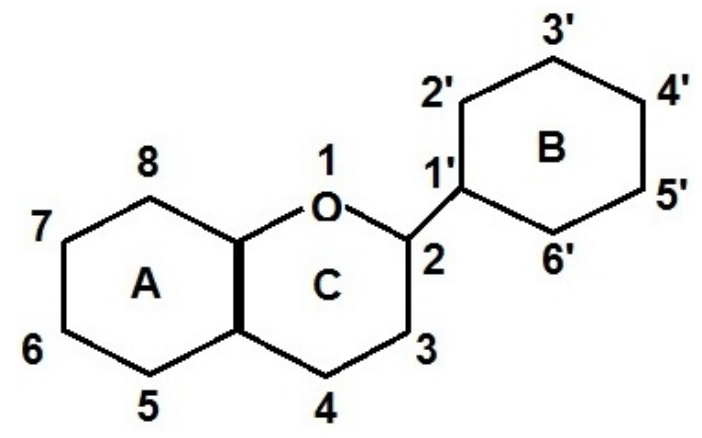

Figure 1. General structure of a flavonoid [10]

Isoflavones are phenolic compounds found mainly in beans and soybean derivatives and vary in concentration from 0.1 to $5 \mathrm{mg} / \mathrm{g}$. They are distinguished by the substituents on the 
benzene ring, which are classified into 4 distinct forms: $\beta$-glycosides (daidzin, genistin and glycitin), acetyl-glycosides (acetyldaidzin, acetylgenistin and acetylglycitin), malonyl-glycosides (malonyldaidzin, malonylgenistin and malonylglycitin) and aglycones (daidzein, genistein and glycitein). As a result, there are a total of 12 different forms, with the $\beta$-glycoside forms bonded at position 7 of the benzene ring to a glucose molecule (Figure 2). The consumption of isoflavones is related to the prevention of several diseases, such as breast cancer, colon cancer and cardiovascular problems. In a study performed by Silva, CarrãoPanizzi and Prudêncio (2009) comparing different varieties of soybean, the authors found a prevalence of glycosidic and malonyl-glycosidic isoflavones in the beans, with higher levels of the aglycone forms in the BRS 267 soybean variety with cooking [10,13-15].

According to Arora, Nair and Strasburg et al. (1998), all isoflavone forms display antioxidant action, which varies widely according to the structure. In addition, the genistein form, with hydroxyl groups at positions 5, 7 and 4, has a greater antioxidant strength, which is evident by its structure, as shown in figure 2.

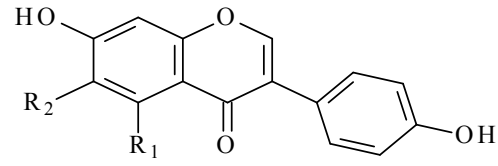

Aglycones

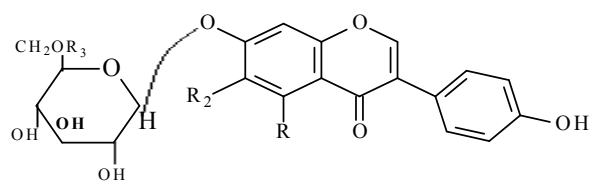

Glucosides

\begin{tabular}{ccccc}
\hline $\mathrm{R}_{1}$ & $\mathrm{R}_{2}$ & $\mathrm{R}_{3}$ & Compounds \\
\hline $\mathrm{H}$ & $\mathrm{H}$ & - & daidzein \\
$\mathrm{OH}$ & $\mathrm{H}$ & - & genistein \\
$\mathrm{H}$ & $\mathrm{OCH}_{3}$ & - & glycitein \\
daidzin \\
$\mathrm{H}$ & $\mathrm{H}$ & $\mathrm{H}$ & genistin \\
$\mathrm{OH}$ & $\mathrm{H}$ & $\mathrm{H}$ & glycitin \\
$\mathrm{H}$ & $\mathrm{OCH}_{3}$ & $\mathrm{H}$ & 6"-O-Acetyldaidzin \\
$\mathrm{H}$ & $\mathrm{H}$ & $\mathrm{COCH}_{3}$ & 6"-O-Acetylgenistin \\
$\mathrm{OH}$ & $\mathrm{H}$ & $\mathrm{COCH}_{3}$ & 6"-O-Acetylglycitin \\
$\mathrm{H}$ & $\mathrm{OCH}_{3}$ & $\mathrm{COCH}$ & 6"-O-Malonyldaidzin \\
$\mathrm{H}$ & $\mathrm{H}$ & $\mathrm{COCH}_{2} \mathrm{COOH}$ & 6"-O-Malonylgenistin \\
$\mathrm{OH}$ & $\mathrm{H}$ & $\mathrm{COCH}$ & $\mathrm{COOH}$ & 6"-O-Malonylglycitin \\
$\mathrm{H}$ & $\mathrm{OCH}_{3}$ & $\mathrm{COCH}{ }_{2} \mathrm{COOH}$ &
\end{tabular}

Figure 2. Chemical structures of the 12 isoflavones found in soybean [10] 
Chaiyasut et al. (2010) evaluated the effect of the time of Aspergillus oryzae fermentation in soybean on the isoflavone profile and the antioxidant capacity through ABTS cation (2,2'azinobis-[3-ethylbenzthiazoline-6-sulfonic acid]) and iron reduction (FRAP) assays. According to the authors, there was a significant increase in aglycone isoflavones (daidzein and genistein) and a reduction in glycosilades (daidzin and genistin) with a longer exposure time to the fermentation process. This trend was reflected in the antioxidant activity, with the greater antioxidant capacity displayed by samples with a longer fermentation time due to an increase in the aglycone forms. These results were similar to those found by Barbosa et al. (2006), who evaluated the isoflavone profile and the amount of phenolic compounds in different soybean-based products and the influence of these products on the antioxidant capacity. Their results showed that the antioxidant capacity is related not only to the amount of total phenolic compounds but also to the amount and forms of the aglycones and the types of conjugation.

However, anthocyanins are considered to be natural pigments, as they exhibit colours that are visible to the human eye and may be found in flowers, fruits and vegetables. Anthocyanins belong to the flavonoid group and are not synthesised by the human body; when ingested, they help the immune system by decreasing the action of radicals formed during respiration, and they are naturally found in several plants $[19,20]$.

Anthocyanins are glycosides of anthocyanidins (Figure 3) and may have different sugars bonded to their ringed structure. They are classified as mono, di or triglycosides, and the diglycoside and triglycoside forms are more stable than the monoglycoside forms. They display colour variations according to their structural forms, $\mathrm{pH}$ value, number of hydroxyls and methoxyls and temperature [21-23].

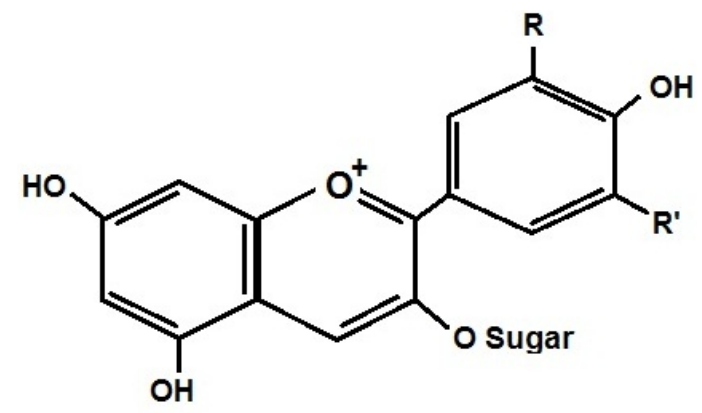

Anthocyanin

Figure 3. General structure of an anthocyanin [23]

According to Levi et al. (2004), there may be 4 structures in an aqueous medium depending on the $\mathrm{pH}$ value: the flavylium cation, the quinoidal base, carbinol and chalcone (Figure 4). 
<smiles>[R]c1cc(-c2oc3cc(=O)cc(O)c-3cc2O)cc([R])c1O</smiles>

Quinoidal base (A): blue

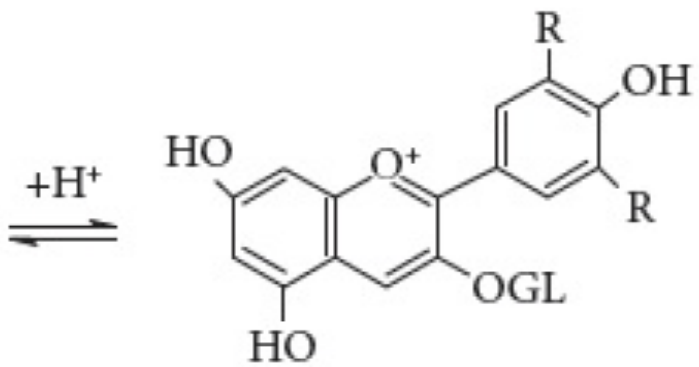

Flavilium cation $(\mathrm{AH}+)$ : red<smiles>[R]c1cc(C(=O)/C(=C\c2c(O)cc(O)cc2O)OCl)cc([R])c1O</smiles>

Chalcone (C): colorless

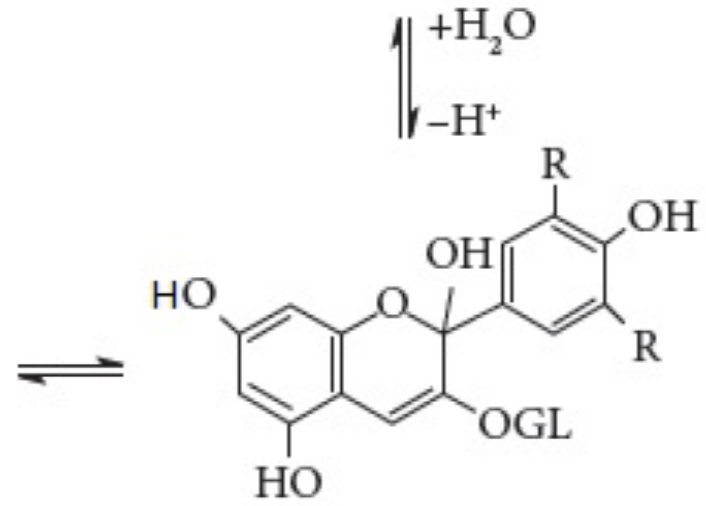

Carbinol (B): colorless

Figure 4. Molecular structures found at different $\mathrm{pH}$ values [24]

Kahkonen et al. (2003) isolated and identified the anthocyanins present in bilberry, blackcurrant and cowberry and evaluated their antioxidant activities through in vitro DPPH (2,2-diphenyl-1-picrylhydrazyl) assays with emulsified methyl linoleate and LDL (human low density lipoprotein). They found that the amounts of anthocyanins for bilberry, blackcurrant and cowberry were 6000,2360 and $680 \mathrm{mgkg}^{-1}$ of the fresh weight, respectively; all samples exhibited high activity in the DPPH tests and were effective antioxidants for the emulsion of methyl linoleate and human LDL. Rufino et al. (2010) studied the antioxidant strength of açaí (Euterpe oleraceae) with the aim of using it in functional foods and dietary supplements and found an antioxidant capacity for acai oil in the DPPH assay that was higher $(\mathrm{EC} 50=646.3 \mathrm{~g} / \mathrm{g}$ DPPH) than the value for virgin olive oil (EC50=2057.27 g/g DPPH), indicating its considerable potential for nutritional and health applications. 


\section{Non-dairy matrices as vehicles for probiotics and viability}

Currently, there is increasing consumer interest in probiotic foods as an alternative to improve health. The majority of probiotic products found on the market are milk based, including milk drinks, yogurts, cheese and ice cream. Despite being an ideal substrate for the growth of these microorganisms, dairy products have several disadvantages, such as the need for refrigerated transportation, their cholesterol content and the restriction of their consumption to individuals who are not intolerant of or allergic to the products [27].

Thus, the development of new alternatives for consumption has increasingly earned the attention of the scientific and industrial communities, and new products, such as those based on soybeans, cereals, fruits, vegetables and meats, are being developed as potential carriers. In addition, these non-dairy matrices contain reasonable amounts of carbohydrates, fibres, proteins and vitamins, which may beneficially favour the growth and maintenance of the probiotics [27].

The viability and stability of probiotics have been a formidable market and technological challenge for food producers, given that probiotic foods should contain specific lineages and maintain an appropriate level of viable cells during the product's shelf life. Before they reach consumers, probiotics need to be produced under industrial conditions and maintain their functionality during storage in the form of a starter culture. Then, they need to be able to survive the processing of the food to which they are added. Finally, when ingested, the probiotics need to survive under the harsh conditions of the gastrointestinal tract and perform their beneficial effects in the host. In addition, they must be incorporated into the foods without producing unpleasant flavours or textures [28].

The application of probiotics in non-dairy matrices must be evaluated, given that several factors may influence the survival of these organisms and their activity when they pass through the gastrointestinal tracts of consumers. The following are among the factors that should be considered: the physiological state of the added probiotic organism as a function of the logarithmic or stationary growth phase; the appropriate concentration of viable cells in the product at the time of consumption; the physical conditions, such as low temperatures, during product storage; and the chemical composition of the product to which the probiotic is added, such as the $\mathrm{pH}$, water content and amounts of carbon, nitrogen, minerals and oxygen [29].

Alternative vehicles for the incorporation of probiotic microorganisms may be fruits and fruit juices, but maintaining their viability is challenging because the $\mathrm{pH}$ of fruits and fruit juices is frequently low $(<4.0)$. They also contain antimicrobial substances. To minimise these factors, fruit juice may be formulated to have a higher $\mathrm{pH}$ value and smaller amounts of antimicrobial substances [30]. Sheehan, Ross and Fitzgerald (2007) evaluated the survival of several probiotic lineages in orange, pineapple and cranberry juices and observed that in addition to the juice's $\mathrm{pH}$, the probiotic lineage and type of fruit also influenced the counts of the final product. 
Pereira, Maciel and Rodrigues (2011) obtained a survival value of $8 \log$ UFC/mL of L. casei in fermented cashew juice when the initial $\mathrm{pH}$ was 6.4 and the fermentation temperature was $30^{\circ} \mathrm{C}$. Yoon, Woodams and Hang (2004) also reported viable cell counts of more than $8.0 \mathrm{log}$ CFU/mL in tomato juice. In addition, L. acidophilus, L. plantarum, L. casei and L. delbrueckii were capable of rapidly using this juice for cellular synthesis without nutrient supplementation. In another study by the same researchers, the fermentation of beets by probiotic bacteria was also investigated, and the authors observed a cellular survival of $10^{9} \mathrm{UFC} / \mathrm{mL}$ of juice after 48 hours of fermentation in this substrate [34].

Lima, (2010) studied the behaviour of probiotic microorganisms in different tubers. Beetroot (Beta vulgaris) displayed the best survival results compared with sweet potato and arracacha. Upon adding pure betaine to the samples before fermentation and dehydration to supplement the amount of betaine already present in beetroot, the counts of L. plantarum and $L$. rhamnosus (LPRA Clerici-Sacco culture) were maintained at $8 \log$ CFU/g of dehydrated sample (Figure 5).

To increase the robustness of the probiotic lineage of Lactobacillus salivarius UCC118, Sheehan et al. (2007) in a previous study cloned the betL gene of Listeria monocytogenes enables the system to capture or accumulate compatible solutes, such as betaine. BetL increases the tolerance to salt, low temperature and pressure stress as well as increases the viability of the probiotic in foods.

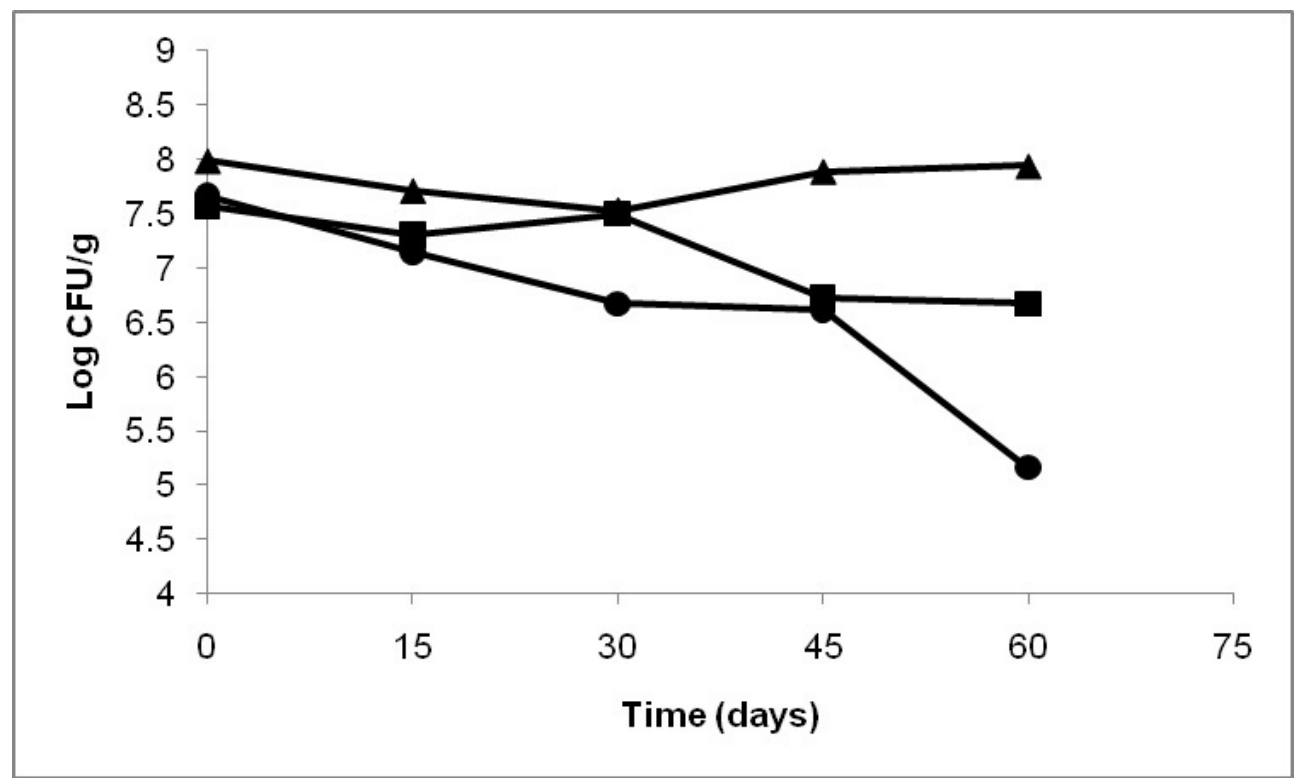

Figure 5. Behaviour of LPRA culture (composed of Lact. plantarum and Lact. rhamnosus) in assays 1, 2 and 3 during storage for 60 days at $25^{\circ} \mathrm{C}$. Assay $1(\bullet)$ : beet; assay 2 ( $\left.\mathbf{\square}\right)$ : Beet $+0.5 \mathrm{mM}$ betaine; assay $3(\boldsymbol{\Lambda})$ : Beet $+2 \mathrm{mM}$ betaine 
In addition to studies focusing only on the survival of probiotics in alternative matrices, for these products to be fit for human consumption and compatible with industrial production, evaluating the sensory quality of the formulated products is important. In this context, Ellendersen et al. (2012) developed and optimised a probiotic drink composed of apple juice and established the sensory profile using quantitative descriptive analysis (QDA). Sensorially, apple juice recently fermented with L. casei was characterised as having a thick texture and sweet flavour, but at 28 days of storage, a sour taste was observed by the tasters. When the fermented drink was tested by potential consumers, a rate of $96 \%$ acceptance was obtained, indicating that apple juice may be a medium for the inclusion of probiotics. Baptista, (2010) used orange peels with a pectin content of $19.3 \%(\mathrm{p} / \mathrm{p})$ and a subsequent fermentation by a starter culture (Lyofast M36 LV) of kefir in milk serum and dehydrated the product, which was used to produce a cereal bar. An average acceptance rate of 6.97 (in a structured Hedonic scale of nine points) for samples without the peel and 6.90 for samples containing the dehydrated probiotic was obtained (the samples did not differ between one another at a level of $\mathrm{p}<0.05$ ). The counts of Lactococcus lactis found in the product were $5.4 \times 10^{7} \mathrm{CFU} / \mathrm{g}$.

Cereals are considered one of the most important sources of proteins, carbohydrates, vitamins, minerals and fibres. The traditionally fermented products of cereals exhibit modified textures, tastes, aromas and nutritional qualities and are widely consumed in Asia, Africa, South America and India. The fermentative process of these foods, in addition to improving the nutritional value, contribute to increasing its preservation via the production of alcohols and acids and reduction in the amount of toxic substances and cooking time for the cereal [29].

According to Charalampopoulos et al. (2002), the possible applications of cereals or cereal constituents in the formulation of functional foods may include the following: (a) as a fermentable substrate for the growth of probiotic microorganisms, especially lactobacilli and bifidobacteria; (b) as a dietary fibre promoting various beneficial physiological effects; (c) as a prebiotic due to its specific non-digestible carbohydrate content; and (d) as encapsulating materials for probiotics to increase their stability.

Thus, several studies have been performed to bind probiotic microorganisms to cereal matrices. Charalampopoulos, Pandiella and Webb (2003) verified the viability of Lactobacillus plantarum, L. acidophilus and L. reuteri in extracts of malt, barley and wheat for 4 hours in a phosphate buffer with an acidity of $\mathrm{pH}$ 2.5. They observed that these cereals displayed a significant protective effect toward the viability of these microorganisms, which may mainly be attributed to the amount of sugar present in these extracts. In 2010, Charalampopoulos and Pandiella evaluated the survival of Lactobacillus plantarum in extracts of barley, wheat and malt that were produced in suspensions of flour/water at concentrations of $5 \%, 20 \%$ and $30 \%$, fermented for 24 hours at $37^{\circ} \mathrm{C}$ and stored at $4^{\circ} \mathrm{C}$ for 70 days. The authors observed that the cells displayed greater survival when they were stored in a medium containing malt extract, and this result was attributed to the higher concentration of sugar and the presence of other unidentified compounds.

Rathore, Salmerón and Pandiella (2012) used malt, barley and a mixture of malt and barley as substrates in the fermentation of Lactobacillus plantarum and Lactobacillus acidophilus with 
the objective of evaluating the influence of the lineages and the matrices used for the production of a probiotic beverage. The authors observed that a higher level of cellular growth was obtained in the medium that contained malt. In addition, these results suggested that the functional and sensory properties of probiotic beverages based on cereals may be considerably modified by changes in the composition of the substrate or the inoculum.

Oats, one of the major sources of beta-glucan, are commonly used in studies with probiotics. Guergoletto et al. (2010a) achieved a high level of survival for L. casei attached to oat bran when undergoing the vacuum drying process. Angelov et al. (2006), after optimising several factors such as the concentrations of the starter culture, oat flour and sucrose, developed an oat beverage fermented with $L$. plantarum, obtaining approximately $7.5 \times 10^{10} \mathrm{CFU} / \mathrm{mL}$ of probiotics at the end of the process.

Another interesting application of probiotic microorganisms would be the enrichment of chocolate. With the development of technologies modified and adapted to maintain cells, this process may contribute toward increasing the benefit of this product for human health and increasing the consumption of probiotics by children, given that chocolate is one of their favourite products. For this combination to be successful, the sensory attributes of chocolate must remain unaltered, and the probiotic population must remain viable during commercialisation [44].

Finally, the application and development of new probiotic products of a non-dairy origin continue to grow. In light of the studies that have been presented by the scientific community, minimising the difficulties found in the application of these microorganisms in other food segments is possible.

\section{Non-traditional fermented soybean-based products}

Soybean is a plant that has been consumed since ancient times and is known worldwide for its nutritional benefits; it has a composition of approximately $40 \%$ proteins, 35\% carbohydrates, $20 \%$ lipids and $5 \%$ ash [10]. In addition, soybean contains a considerable amount of components that are beneficial to health, such as fibres, isoflavones, essential fatty acids and oligosaccharides.

Traditionally, soybean-based products may be fermented by bacteria and/or fungi, with the most well-known being koji, shoyu, miso, tempeh, natto and sufu. These products are traditionally consumed by the East Asian population and represent an important source of dietary protein.

The search for foods that offer health benefits in addition to basic nutrition has promoted the development of new products that are based mainly on soymilk, which is obtained from the aqueous extraction of the bean's components. Soymilk possesses a chemical composition and appearance similar to those of animal milk and constitutes an appropriate substrate for fermentation; it contains, on average, $3.6 \%$ protein, $2.0 \%$ lipids, $2.9 \%$ carbohydrates and $0.5 \%$ ash [10]. Although studies have shown an increase in the consumption of soymilk, 
there are still technological limitations with regard to its sensory characteristics due to the perception of undesirable flavours that were inherent in the extract or that were formed during the processing $[45,46]$. Fermentation, especially by lactic bacteria, has been used to improve the flavour and increase the acceptability of soymilk and sometimes, to decrease the levels of saponin, phytate and oligosaccharides [47, 48].

Soybean-based products that are analogous to the products derived from milk have been developed and are widely consumed. In general, these products are not cheaper than dairy products, yet they meet the growing demand for lactose- and cholesterol-free products. The main products developed in this segment are beverages, yogurt and cheese made from soybean, which are sought by consumers looking for healthier foods. The fermentation of soymilk by lactic bacteria, in addition to increasing shelf-life, is aimed at obtaining products with flavours and textures that are more acceptable to consumers [47]. In general, the microorganisms that are utilised are capable of using soybean sugars, or sucrose may be added as a substrate for fermentation. Table 1 shows several non-traditional fermented soybean products and the respective microorganisms used in their production.

\begin{tabular}{|c|c|c|}
\hline Product & Microorganisms used & Reference \\
\hline \multirow[t]{2}{*}{ Soy yogurt } & $\begin{array}{l}\text { Streptococcus thermophilus, L. delbrueckii subsp. bulgaricus } \\
\text { and L. johnsonii, L. rhamnosus and bifidobacteria }\end{array}$ & Farnworth et al. (2007) \\
\hline & $\begin{array}{l}\text { L. delbrueckii subsp. bulgaricus and Streptococcus } \\
\text { thermophilus }\end{array}$ & Rinaldoni et al. (2012) \\
\hline \multirow[t]{2}{*}{ Fermented soy beverage } & Bifidobacteria & Chou and Hou (2000) \\
\hline & Streptococcus thermophilus and L. helveticus & $\begin{array}{l}\text { Champagne et al. } \\
\text { (2010) }\end{array}$ \\
\hline \multirow[t]{2}{*}{ Kefir } & $\begin{array}{l}\text { L. delbrueckii subsp. lactis, L. helveticus, L. rhamnosus and } \\
\text { Bifidobacterium longum and Streptococcus thermophilus }\end{array}$ & $\begin{array}{l}\text { Champagne et al. } \\
\text { (2009) }\end{array}$ \\
\hline & $\begin{array}{l}\text { Lactococcus lactis ssp. lactis, Lactococcus lactis spp lactis biovar } \\
\text { diacetylactis, L. brevis, Leuconostoc and Saccharomyces } \\
\text { cerevisiae. }\end{array}$ & Baú (2012) \\
\hline \multirow[t]{2}{*}{ Custard } & $\begin{array}{l}\text { Commercial kefir culture - Streptococcus lactis, Streptococcus } \\
\text { cremoris, Streptococcus diacetylactis, L. plantarum, L. casei, } \\
\text { Saccharomyces fragilis and Leuconostoc cremoris }\end{array}$ & $\begin{array}{l}\text { McCue and Shetty } \\
(2005)\end{array}$ \\
\hline & Kefir grains & $\begin{array}{l}\text { Sánchez-Pardo et al. } \\
\text { (2010) }\end{array}$ \\
\hline Soy cheese & L. rhamnosus & Liu et al. (2006) \\
\hline
\end{tabular}

Table 1. Non-traditional fermented soybean products

Several studies on the survival of probiotic microorganisms indicate that soybean is an appropriate substrate for the growth of several probiotic species, such as bifidobacteria and 
several lactobacilli, such as L. casei, L. helveticus, L. fermenti, L. reuteri and L. acidophilus. Therefore, new probiotic products based on soybean are being continuously developed, exploring the potential that soybean has as a vehicle for functional ingredients.

\subsection{Fibre in non-traditional fermented soybean-based products}

The development of ingredients and products rich in fibre has significantly increased and involves the incorporation of fibre into a wide variety of products, including those made from soybean, with the aim of improving the dietary habits of the population.

In addition to performing physiological functions that are beneficial to the human body, when added to food products, fibre may change the sensory characteristics and consumer acceptance as well as the product's cost and stability. The addition of fibre may affect the processing and handling of the products, with changes in the viscosity, texture, creaminess, syneresis, acidity, colour and other characteristics [49]. In fermented foods, fibre may change the fermentative ability of the products and, in some cases, may protect probiotic microorganisms under stress conditions. Soluble fibre can also be fermented by bacteria in the colon, giving rise to short-chain fatty acids, mainly acetate, propionate and butyrate. In contrast, insoluble fibres are not very fermentable. Furthermore, some types of fibre may act as prebiotics, selectively stimulating the growth of some probiotic microorganisms.

The main types of soluble fibre added to products include pectin, inulin, oligofructose, gums, $\beta$-glucan and some non-digestible oligosaccharides. Insoluble fibre mainly comprises cellulose and hemicellulose, with the most common sources being legumes and cereals, such as soybean, rice, corn, oats and wheat. In general, some sub-products have been used as an alternative for the incorporation of fibre into products as in the case of okara, which is the residue from producing soymilk and has a significant amount of fibre and other important compounds, such as proteins and isoflavones.

In fermented soybean products, the addition of inulin and oligofructose in soybean yogurt has been reported [50], and soybean, oat and wheat fibre have been added to soybean kefir [49]. In the soybean product fermented with kefir, the soybean fibre stimulated the growth of a probiotic microorganism and promoted an increase in firmness and viscosity and a decrease in the synerisis of the product. Yeo and Liong (2010) supplemented WSSE with the prebiotics maltodextrin, pectin, inulin and fructooligosaccharides and observed an alteration in the lactic bacteria count and other characteristics.

Therefore, it is possible different uses of soybean in human food, including being a source of fibre and providing foods with high nutritional value to meet the population's demand for healthy foods.

\section{Products developed for individuals with celiac disease}

Increasing our knowledge on the relationship between diet and health has caused consumers to look for high nutritional value, additional health benefits, convenience and pleasant sensory characteristics in processed products. In addition to this demand, a portion of the 
population is allergic to gluten. For this group, the treatment is essentially based on diet modification, which consists of eliminating gluten. The appropriate foods for individuals who are allergic to gluten are restricted and normally expensive, given that during processing, naturally gluten-free products may experience contamination that is unacceptable for those with celiac disease.

Celiac disease (CD) is an immune-mediated enteropathy triggered by the ingestion of wheat gluten (Triticum aestivum and T. durum) and similar proteins from rye (Secale cereale) in genetically susceptible individuals. During proteolytic digestion, prolamins (secalins) from rye and those in a subgroup of wheat (a-, b-, g- and w-gliadin) release a family of polypeptides rich in Pro and Gln that is responsible for the auto-immune response in celiac enteropathy [51]. The disease corresponds to hypersensitivity to gliadin (protein portion of gluten), which may be found in wheat, rye, barley and oat, and this hypersensitivity is marked by intense inflammatory processes. The consumption of cereals that contain gluten by individuals with celiac disease harms the small intestine [52], causing atrophy and a flattening of the intestinal villi, thereby leading to a limitation of the area available to absorb nutrients, among other manifestations. Situations such as travelling, eating outside the home and even enjoying relationships with friends and families may represent difficulties for celiac sufferers, thus interfering in their social lives [53]. With this disease, the processes of digestion and absorption may be compromised due to the increase in the immune activation of the intestinal tract. Celiac disease is one of the main causes of malabsorption in developed countries [54].

Therefore, there is a search for healthy foods that contain a variety of sensory attributes to allow for the possibility of providing a diverse selection of these foods. However, even with these possibilities, the celiac population is deprived of the consumption of many foods given that the formulations contain cereal-derived ingredients that contain gluten, such as oat flakes, wheat flour and malt.

Therefore, the development of new products for this population is essential, which may be performed by incorporating ingredients that contribute to an increase in mineral absorption, such as the fructans of inulin and oligofructose and other gluten-free bases. Fructans are soluble dietary fibres that may contribute to an increase in the absorption of minerals through colonic absorption $[55,56]$; this effect may be especially important for those with celiac disease, given that the absorption of calcium in the small intestine is impaired in these individuals [57]. Capriles and Gomes Arêas (2010) developed amaranth bars with different flavours through the addition of inulin and oligofructose and observed that the amaranth bars enriched with these fructans may contribute to greater compliance by those with celiac disease to a gluten-free diet and help increase the absorption of calcium. These bars also have a reduced energy content and a high fibre content.

Other alternatives available for the celiac population include the substitution of the wheat flour that is present in several foods, such as breads, cakes, biscuits and pasta, with a mixture of flours that contain rice cream, tapioca flour, potato starch or corn starch, among other products. 
Also notable is the use of soluble fibre such as Psyllium - Plantago ovate [59]. The main component of psyllium is mucilage (made up of slightly branched polysaccharides, found in algae and seeds), which represents 10 to $30 \%$ of its structure. These types of fibre also contain lipids, proteins, oxalic acid and the enzymes invertase and emulsin. Psyllium is considered to be a prebiotic food and is used either pure or in preparations to improve intestinal constipation [60]. With the double function of substituting for wheat in the development of special foods, psyllium has been added to bread dough, which is traditionally made with wheat flour, to improve the characteristics obtained via water retention and gelatinisation [61].

In a study performed by Zandonadi, 2006, psyllium was added to breads, biscuits, pasta, cake and pizza dough, and these products could be classified as foods for special purposes because they reduce the gluten fraction and exhibit good acceptability both by those with and without celiac disease. In addition, they reduce the lipid fraction and thus the product's energy values.

Given the importance of seeking alternatives that promote sensory and functional characteristics that are similar to those of products prepared with gluten, Stork et al. (2009) studied two protein and transglutaminase sources in bread from rice flour to produce a better-quality bread. They observed that rice flour may be enriched with albumin and casein modified by transglutaminase to improve the bread's nutritional quality.

Figueira et al. (2011) evaluated the characteristics of gluten-free breads produced with rice flour and enriched with the microalga Spirulina platensis, which is a microalga that has an appropriate composition for use as a food complement, that have a possible use in combating malnutrition [65]. The dry composition of Spirulina platensis contains high amounts of proteins (64-74\%), polyunsaturated fatty acids and vitamins [66] and contains antioxidant compounds [67]. This microalga is classified as GRAS ("generally recognised as safe") by the FDA, which ensures it can be used as a food without health risks [68]. The authors recommend the use of S. platensis for the enrichment of gluten-free breads made from rice flour using a suggested microalga concentration of $3 \%$, and these bread are appropriate for celiac patients.

In a study on quinoa flour, Berti et al. (2004) evaluated the triglyceride and free fatty acid levels and glycaemic and insulinaemic responses in individuals with celiac disease and showed that the foods prepared with quinoa flour resulted in improved measures for all of these factors compared with the foods prepared with common flours. They also found that satiety was higher in the ingestion of products prepared from quinoa flour.

The use of kefir, which may act as an anti-inflammatory agent, may provide satisfactory results in patients with celiac disease. For these individuals, kefir may help to combat the nutritional deficiencies resulting from the reduction in intestinal villi because kefir is rich in vitamin B12, thiamine and potassium, which increase the absorption of the vitamin B complex $[70,71]$.

Mixtures of several LAB were capable of hydrolysing 109 out of 129 ethanol-soluble polypeptides of rye, and De Angelis et al. (2006) concluded that long-term fermentation by selected LAB may be a potential tool to decrease the risk of contamination with rye in glutenfree products for patients with celiac disease. 
Green banana flour may also be an alternative for the celiac population because the cost is not high, it is easy to prepare, and it exhibits a high amount of resistant starch, approximately $74 \%$ of its composition. This high level of starch is related to its glycaemic index and ability to reduce cholesterol levels and promote gastric fullness and intestinal regulation, and its fermentation by intestinal bacteria produces short-chain fatty acids that may prevent the emergence of cancer in intestinal cells [72]. Given these observations, Zandonadi (2012) evaluated the development of a gluten-free pasta alternative for those with celiac disease using green banana flour and demonstrated good acceptance without compromising the product while imparting important nutritional characteristics.

However, in foods that are thermally processed, especially breads, the lack of gluten represents a challenge in maintaining good sensory qualities, especially in the structure or softness during storage. The use of fermented dough (sourdough) by baker's yeast resulted in an improvement of the texture and effectively delayed the hardening of the gluten-free breads [74]. Fermented doughs also provided the breads with characteristics such as starch digestibility and low glycaemic responses, thereby proving to be a promising procedure in the improvement of the texture of gluten-free breads for those with celiac disease [75]. Galle et al. (2012) studied the influence of the in situ formation of EPS from LAB on the rheology of the dough for gluten-free sorghum bread. Among the EPSs, dextran improved the texture quality of the bread in addition to contributing to the nutritional benefits.

Therefore, the search for and development, market availability, diversification, cost compatibility and even improvement of already existing products for the celiac population all need to increase not only to improve the selection or consumption of these foods but also to ensure a better quality of life for the individuals who require a gluten-free diet.

\section{Probiotics, metabolic action and vehicles of bioactive compounds}

Through fermentation, toxic compounds may be hydrolysed and transformed into derivatives that are more or less absorbable or less toxic. Several studies describe the reduction of toxic or mutagenic compounds following fermentation or in the presence of microorganisms. In most cases, the microbial cells adsorb these compounds, and this process is normally increased with thermal treatment of the cells; the result is the possibility of reducing or degrading the compounds, but this latter mechanism is still not yet completely understood. Franco et al. (2010) observed a gradual increase in the reduction of the percentage of deoxynivalenol in solution depending on whether the LAB cells were viable or thermally inactivated (Table 2).

Other toxic compounds that could be degraded with this approach are toxins produced by algae. Considering the increase in the occurrence of cyanobacterial blooms and the possibility of metabolites being released into water supply sources used for human consumption, Guergoletto et al. (2010b) studied the microcystin (MC) biodegradation activities of microorganisms in water (Figure 6). Their work evaluated the use of the probiotic bacteria Lactobacillus acidophilus (La-5) and Lactobacillus casei (LC-1) and kefir grains for MC degradation over time. The mixtures were maintained at $27^{\circ} \mathrm{C}$ and $100 \mathrm{rpm}$, and samples were collected at $0,12,24,48,72$ and 
$96 \mathrm{~h}$ to determine the level of MCs by immunoassay ELISA. The results indicated that the highest degradation percentage was obtained for kefir grains, reaching $60 \%$ and $62 \%$ of the total MC degradation for Microcystis sp. and NPLJ4 extracts, respectively, followed by the La-5 strain with levels of $43 \%$ and $51 \%$. For LC-1, the degradation activities were $20 \%$ and $34 \%$ for Microcystis sp. and NPLJ4 extracts, respectively, but significant cellular growth was not verified when compared with the La-5 strain (Figures 7A and 7B).

\begin{tabular}{|c|c|c|c|}
\hline \multirow[t]{2}{*}{ Microorganism } & \multicolumn{3}{|c|}{ Reduction Percentage (\%)* } \\
\hline & Viable cells** & $\begin{array}{l}\text { Unviable } \\
\text { cells following } \\
\text { pasteurisation*** }\end{array}$ & $\begin{array}{l}\text { Unviable } \\
\text { cells following } \\
\text { sterilisation**** }\end{array}$ \\
\hline Lyofast LPRA & $52.07 \pm 0.1^{\mathrm{aB}}$ & $53.18 \pm 2.06^{\mathrm{cB}}$ & $70.32 \pm 1.65^{\mathrm{aA}}$ \\
\hline Lyofast BG 112 & $52.62 \pm 4.95^{\mathrm{aB}}$ & $67.45 \pm 2.95^{\mathrm{aA}}$ & $71.19 \pm 2.77^{\mathrm{aA}}$ \\
\hline Lyofast LA3 & $39.23 \pm 2.22^{b c}$ & $60.67 \pm 1.34^{\mathrm{bB}}$ & $66.71 \pm 1.82^{\mathrm{aA}}$ \\
\hline LC 01 & $40.61 \pm 1.19^{\mathrm{bB}}$ & $64.03 \pm 0.07^{\mathrm{abA}}$ & $66.56 \pm 2.43^{\mathrm{aA}}$ \\
\hline Yo flex YC 180 & $31.25 \pm 0.89 c c$ & $57.43 \pm 0.95^{\mathrm{bB}}$ & $65.64 \pm 0.77^{\mathrm{aA}}$ \\
\hline Florafit LP 115 & $32.61 \pm 1.38^{c c}$ & $40.81 \pm 0.95^{\text {deB }}$ & $58.51 \pm 1.29^{c A}$ \\
\hline Yo mix & $40.67 \pm 0.76^{\mathrm{bB}}$ & $41.98 \pm 0.45^{\mathrm{deB}}$ & $48.75 \pm 1.81^{\mathrm{CA}}$ \\
\hline Choozit Helv A & $55.30 \pm 1.35^{\mathrm{aB}}$ & $59.05 \pm 0.45^{\mathrm{bAB}}$ & $63.84 \pm 0.16^{\mathrm{abA}}$ \\
\hline L. plantarum TG VIII & $29.86 \pm 1.18^{c c}$ & $50.38 \pm 0.46^{\mathrm{cdB}}$ & $56.05 \pm 1.86^{\mathrm{bA}}$ \\
\hline L. plantarum FT VI & $34.88 \pm 0.94^{\mathrm{bcB}}$ & $38.58 \pm 1.66^{\mathrm{eB}}$ & $55.74 \pm 1.25^{\mathrm{bA}}$ \\
\hline L. plantarum GT III & $56.12 \pm 1.02^{\mathrm{aB}}$ & $62.67 \pm 1.09^{\mathrm{abA}}$ & $66.79 \pm 0.43^{\mathrm{aA}}$ \\
\hline L. plantarum FTQ VII & $39.70 \pm 1.93^{b c}$ & $51.37 \pm 1.36^{\mathrm{cB}}$ & $65.26 \pm 1.27^{\mathrm{aA}}$ \\
\hline L. plantarum FB VII & $16.41 \pm 5.35^{d c}$ & $48.34 \pm 1.46^{\mathrm{cdB}}$ & $59.62 \pm 1.02^{\mathrm{bA}}$ \\
\hline L. plantarum FI IX & $39.71 \pm 0.30^{\mathrm{bB}}$ & $44.73 \pm 0.29^{\mathrm{bB}}$ & $57.68 \pm 0.41^{c A}$ \\
\hline L. pentosus SI & $19.51 \pm 4.63^{d c}$ & $35.95 \pm 1.57^{\mathrm{eB}}$ & $47.48 \pm 1.59^{\mathrm{dA}}$ \\
\hline L. paracasei K VI & $29.51 \pm 1.16^{c c}$ & $44.98 \pm 1.77^{\mathrm{dB}}$ & $57.19 \pm 1.04^{\mathrm{CA}}$ \\
\hline
\end{tabular}

The results correspond to the average of duplicates \pm standard deviation. Averages \pm standard deviation in the same column followed by the same lowercase letter do not differ at $p \leq 0.05$. Averages \pm standard deviation in the same line accompanied by the same uppercase letter do not differ at $p \leq 0.05 .{ }^{*}$ Viable cells were separated by centrifugation ( 5 ${ }^{\circ} \mathrm{C} / 3000 \mathrm{~g} / 10$ minutes), washed in PBS pH 7.2 and ultrapure water, resuspended in DON solution with ultrapure water at a concentration of $1500 \mathrm{ng} \mathrm{ml}^{-1}$ and incubated at $37 \pm 1{ }^{\circ} \mathrm{C}$ for 4 hours. ${ }^{* *}$ Nonviable cells following pasteurisation ( $100^{\circ} \mathrm{C} / 30$ minutes) were separated by centrifugation, washed in PBS pH 7.2 and ultrapure water, resuspended in DON solution with ultrapure water at a concentration of $1500 \mathrm{ng} \mathrm{ml}^{-1}$ and incubated at $37 \pm 1{ }^{\circ} \mathrm{C}$ for 4 hours. ${ }^{* * *}$ Nonviable cells following sterilisation $\left(121^{\circ} \mathrm{C} / 15\right.$ minutes) were separated by centrifugation, washed in PBS pH 7.2 and ultrapure water, resuspended in DON solution with ultrapure water at a concentration of $1500 \mathrm{ng} \mathrm{ml}^{-1}$ and incubated at $37 \pm 1^{\circ} \mathrm{C}$ for 4 hours.

Table 2. Reduction of deoxynivalenol level by LAB viable cells and cells that were heat inactivated (unviable) by pasteurisation or sterilisation 

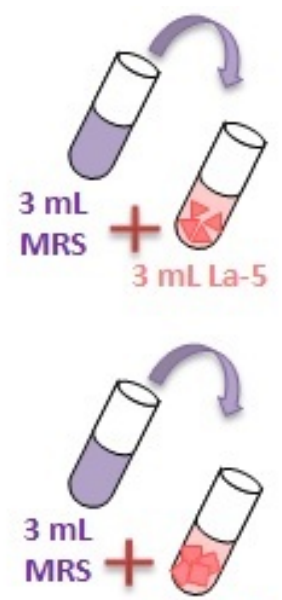

$3 \mathrm{~mL}$ LC-1

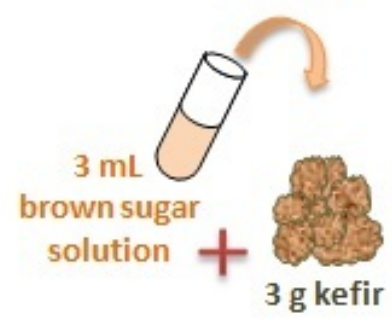

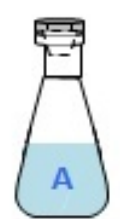

$24 \mathrm{~mL}$ M. sp. extract containing predominantly MC-LR

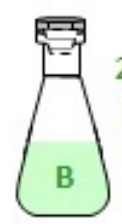

$24 \mathrm{~mL}$ M. sp. NPU4 extract containing predominantly [DLeu $\left.{ }^{1}\right]$ MC-LR

Figure 6. Scheme for the microcystin biodegrading activity experiment Lactobacillus acidophilus (La-5), Lactobacillus casei (LC-1) and kefir grains
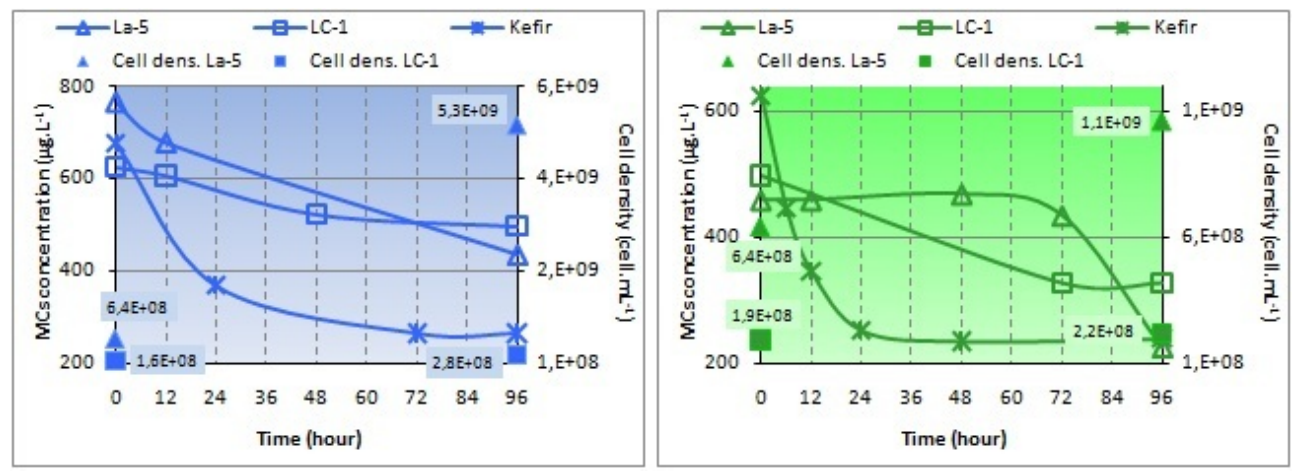

Figure 7. A Degradation kinetics of total MCs by La- 5 and LC-1 bacteria and kefir grains during 96 hours of incubation with Microcystis sp. (A) extract B Degradation kinetics of total MCs by La-5 and LC-1 bacteria and kefir grains during 96 hours of incubation with NPLJ4 (B) extract 
Mutagenic or carcinogenic activity in the caecal or urinary structures may be reduced by the consumption of L. casei shirota (LcS). A mechanism to explain the production of mutagenic substances was described by an in vitro study [79] in which the LcS was capable of strongly adsorbing and inactivating mutagenic pathogens and carcinogens, such as 3-amino-1,4 dimethyl-5H-pyrido (4,3-b) indole-trp-P-1 and 3-amino-1-methyl $5 \mathrm{H}$ pyrido (4,3-b) indole-trp-P-2. LcS also has the ability of binding aflatoxin, a known carcinogen produced by fungi [80].

Multi-functional polysaccharide molecules of plant, algal, bacterial or fungal origins have been extensively studied in recent decades for applications as thickeners, stabilisers, gelling agents, prebiotics and bioremediators or anti-pollutants [81-83]. Until now, plant macromolecules have dominated the market due to their ease and availability and because their purification is cost efficient, as plants are superior primary sources of polysaccharides, including starch, cellulose, pectin and gums. However, because polysaccharides of microbial origin are renewable, have little cost variation and have reproducible physical-chemical properties, they may be of value in certain situations, although they are still not widely marketed and represent an unexplored market [82]. Prasanna et al. (2012) studied the growth, acidification, EPS production and viscosity potential of 22 lineages of Bifidobacterium spp of intestinal origin, and EPSs were produced by Bifidobacterium bifidum ALM 35, B. breve NCIMB 8807 (UCC 2003), B. longum subsp. infantis CCUG 52486 and Bifidobacterium infantis NCIMB 702205 in concentrations varying from 25 to $140 \mathrm{mg}$ L-1, producing an increase in the viscosity of dairy products with a low fat content.

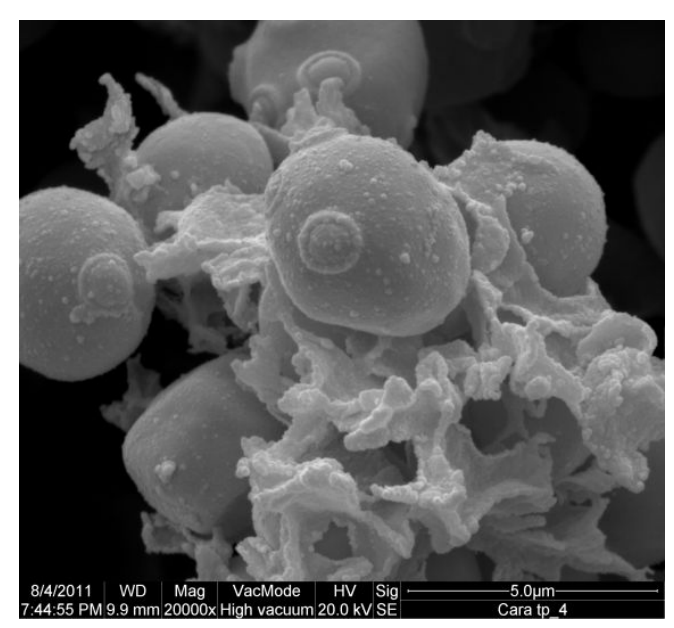

Figure 8. Scanning electron micrographs at magnifications of 20,000x Agar-agar and yam (Dioscorea sp.) microspheres containing Saccharomyces cerevisiae Laboratory of Electron Microscopy and Microanalyses - State University of Londrina.

Laurenti, E. (2010) studied the controlled release of probiotic S. cerevisiae (Biosaf SC-47) from microspheres of agar-agar added to mucilage (Figure 8) and gums and evaluated the poten- 
tial application of these new natural materials for the protection of probiotics using gastrointestinal simulation tests. Okra and flaxseed showed the greatest retention of yeast cells in the microspheres and, consequently, a lower percentage of release at $66.97 \%$ and $72.96 \%$, respectively (Figures 9 and 10).

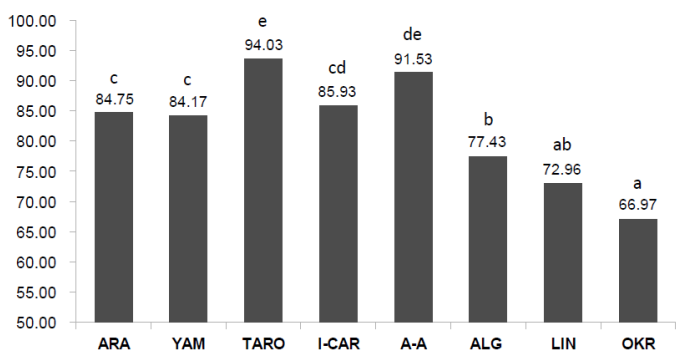

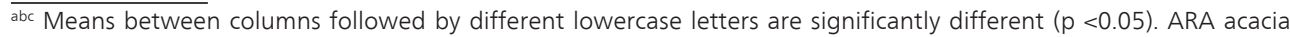
gum; YAM Dioscorea sp; TARO Colocasia esculenta; I-CAR iota carrageenan; A-A agar-agar; ALG alginate; LIN Linun usitatissimum; OKR Hibiscus esculentus.
\end{abstract}

Figure 9. Mean release (\% log CFU/g) of the probiotic S. cerevisiae encapsulated in agar-agar and different gums and mucilages after digestion in vitro

Mean release (\% log CFU/g) of the probiotic S. cerevisiae encapsulated in agar-agar and different gums and mucilages after digestion in vitro

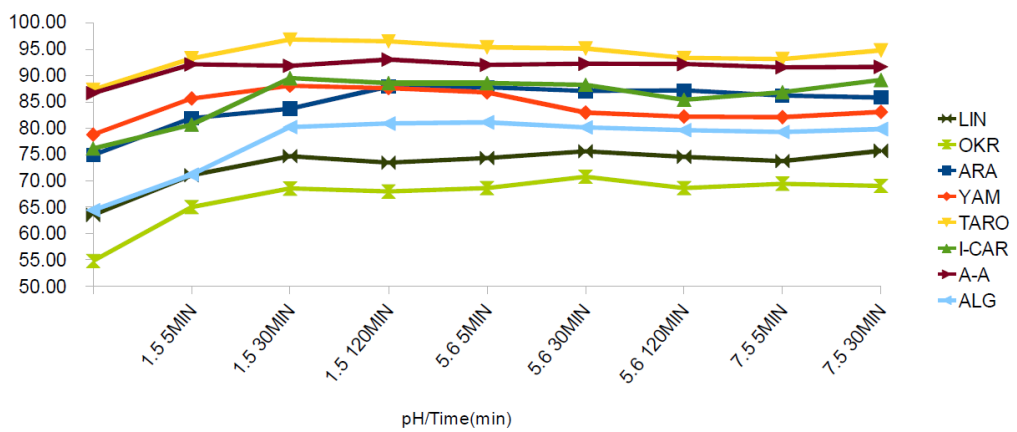

Figure 10. Digestion in vitro of the probiotic S. cerevisiae encapsulated in mucilages and gums. ARA acacia gum; YAM Dioscorea sp; TARO Colocasia esculenta; I-CAR iota carrageenan; A-A agar agar; ALG alginate; LIN Linun usitatissimum; OKR Hibiscus esculentus

Free radicals, especially those belonging to the family of ROS, are increasingly implicated or recognised as the cause of aging and in the pathogenesis of different diseases, such as cancer. Oxidative damage to the cellular molecules caused by chain reactions of free radicals may be combatted by antioxidants or by free-radical-sequestering agents. The use of natural antioxidants with less harmful effects and better bio-acceptability is gradually be- 
coming important. Many plant or microbial polysaccharides have been demonstrated to exhibit sequestering or antioxidant ability due to the abundance of functional groups in the molecule [86]. Pan and Mei (2010) described the antioxidant action of EPS from Lactococcus lactis subsp lactis 12 .

New evidence increasingly suggests the correlation of human IADS with the microbial organisms in the gastrointestinal tract. Specific lineages with physiological and antioxidant activities have a major impact on the management of the levels of oxidative stress in the lumen, among the mucosa cells and even in blood to support the functionality of the IADS in the human body. A lineage of Lactobacillus fermentum ME-3 (LfME-3) with antioxidant, antimicrobial and antiatherogenic properties was patented by the University of Tartu and proven to be 80 to 100 times more potent in vitro in sequestering the superoxide anion radical than Trolox or ascorbic acid. This lineage expresses Mnb superoxide dismutase (Mn SOD) activity, which effectively eliminates hydroxyl and peroxyl radicals and has the complete glutathione system (GSH, GPx, glutathione reductase - Gred) necessary for the recycling, transportation and synthesis of glutathione [5].

According to estimates by the World Health Organization [88], 3.2 million deaths per year are associated with physical inactivity. A sedentary lifestyle, a term derived from the Latin root "sedere", meaning to be seated, includes physical activities with low energy expenditure that are correlated with obesity, metabolic syndrome, type 2 diabetes and cardiovascular diseases (CVD) [89]. Therefore, new approaches are necessary to reduce the risk of CVD, for which prevention via anti-inflammatory agents and antioxidants is considered to be the "third great wave" [90].

In contrast to the traditional action of probiotics involving a direct interaction with the host, the action of LAB in the cardiovascular system occurs via the release of bioactive peptides from proteins by L. helveticus during the fermentation process. A functional dairy product, Cardi- $04^{\mathrm{TM}}$, was developed to reduce blood pressure [91]. A functional cheese with L. plantarum lineage TENSIA (DSM 21380, property of the Bio-competence Centre of Healthy Dairy Products LLC) may reduce blood pressure, both diastolic and systolic (a dose of $10^{10} \mathrm{UFC}$ of viable probiotic cells per daily portion), in adults with high blood pressure or healthy adults and elderly individuals [5].

Recently, new bioactive compounds have been introduced in different medicinal and therapeutic applications. These molecules have been used due to their antioxidant, anti-tumour, anti-inflammatory and anti-viral activities. The EPSs induce cytosine and interferon activity, inhibit platelet aggregation and modulate the immune system [81]. Polysaccharides of Lactobacillus sp. have health benefits. Kefir may be classified as a functional food due to its action at different levels in animals. At doses between 100 and $300 \mathrm{mg} / \mathrm{kg}$ in rats, kefiran reduced blood pressure and the levels of blood sugar and cholesterol and displayed a positive effect toward constipation [92]. Other properties were perceived following the oral administration of this polysaccharide, such as anti-inflammatory and antitumour effects and the stimulation of immunoglobulin secretion. In addition, diosgenin, a steroid saponin present in yams (Dioscorea sp.) and fenugreek, displays properties that 
may be of value in future applications in medicine for the reduction of blood sugar and cholesterol and for the treatment of cholestasis [93].

Hobbs et al. (2012) studied the effect of beet juice and breads with added beets on the change in blood pressure and found strong evidence for a cardioprotective effect and the lowering of blood pressure caused by nitrate-rich plants. Recently, the effect of cardioprotective agents in green-leafed plants and beets has been postulated [95] to be due to the high nitrate content. Given that hypertension is associated with a decrease in the endogenous production of nitric oxide (NO) and that $\mathrm{NO}$ can be produced from the nitrate in the diet, new cost-effective strategies for the incorporation of nitrates in the diet are of considerable interest.

\section{Author details}

Alessandra Yuri Tsuruda, Marsilvio Lima de Moraes Filho, Marli Busanello, Karla Bigetti Guergoletto, Tahis Regina Baú, Elza Iouko Ida and Sandra Garcia

Food Science and Technology Department, State University of Londrina, Londrina, Brazil

\section{References}

[1] Simões CMO, Schenkel EP, Gosmann G, Mentz LA, de Mello Palazzo JC, Schenkel EP. Farmacognosia: da planta ao medicamento. Porto Alegre/Florianópolis: Editora da Universidade UFRGS / Editora da UFSC. 1999819.

[2] Zheng W, Wang SY. Antioxidant activity and phenolic compounds in selected herbs. Journal Agricultural and Food Chemistry. Chicago: 2001; 49 5165-5170.

[3] Wang SY, Zheng W. Effect of plant growth temperature on antioxidant capacity in strawberry. Journal Agricultural and Food Chemistry. Chicago: 2001; 49 4977-4982.

[4] Yildirim A, Mavi A., Kara AA. Determination of antioxidant and antimicrobial activities of Rumex crispus L. extracts. Journal Agricultural and Food Chemistry. Chicago: 2001; 49 4083-4089.

[5] Kullisaar T, Songisepp E, Zilmer M. Probiotics and Oxidative Stress. In: Oxidative Stress -Environmental Induction and Dietary Antioxidants. Lushchak, V.L. Croatia,Intech, 2012 p.203

[6] Halliwell B, Aeschbach R, Loliger J, Aruoma OI. The characterization of antioxidants. Food Chemistry and Toxicology. 1995; 33(7) 601-617.

[7] Brenna OV, Pagliarini, E. Multivariate analyses of antioxidant power and polyphenolic composition in red wines. Journal Agricultural and Food Chemistry. Chicago: 2001; 49 4841-4844. 
[8] Sousa CMD M, Silva HRE, Vieira Jr GM. et al. Total phenolics and antioxidant activity of five medicinal plants. Quimica Nova. 2007; 30(2) 351-355.

[9] BRASIL, Decreto no 50.040, de 24 de janeiro de 1961. Dispõe sobre as Normas Técnicas Especiais Reguladoras do emprego de aditivos químicos a alimentos. Agência Nacional de Vigilância Sanitária (ANVISA), Brasília, 1961.

[10] Liu K. Soybeans: chemistry, technology and utilization. ITP., 1997.

[11] Dornas WC, Oliveira TT, Rodrigues-das-Dores RG, Santos AF, Nagem TJ Flavonóides: potencial terapêutico no estresse oxidativo. Revista de Ciências Farmacêuticas Básica e Aplicada. 2007; 28(3) 241- 249.

[12] Silva JB, Carrão-Panizzi MC, Prudêncio SH. Chemical and physical composition of grain type and food type soybean for food processing. Pesquisa Agropecuária Brasileira. 2009; 44(7) 777-784.

[13] Kudou S, Shimoyamada M, Imura T, Uchida T, Okubo K. A new isoflavone glycoside in soybean seeds (Glycine Max Merrill), glycitein 7-O-beta-D-(6"'-O-acetyl)-glucopiranoside. Agricultural and Biological Chemistry, 1991; 55(3) 859-860.

[14] Setchell KD. Phytoestrogens: The biochemistry, physiology, and implications for human health of soy isoflavones. American Journal Clinical of Nutrition. 1998; 134(6) 1333-1343.

[15] Schwartz SJ, Elbe JHV, Giusti MM. Corantes. In: DAMODARAN, Srinivasan; PARKIN, Kirk L.; FENNEMA, Owen R. Química de Alimentos de Fennema. 4 ed. Porto Alegre: Artmed, 2010. p. 445-498.

[16] Arora A., Nair MG, Strasburg GM. Antioxidant activities of isoflavones and their biological metabolites in a liposomal system. Archives of Bichemistry and Biophysics, 1998; 356(2) 133-141.

[17] Chaiyasut C, Kumar T, Tipduangta P, Rungseevijitprapa W. Isoflavone content and antioxidant activity of Thai fermented soybean and its capsule formulation. African Journal of Biotechnology. 2010; 9 4120-4126.

[18] Barbosa ACL, Hassimotto NMA, Lajolo FM, Genovese MI. Teores de isoflavonas e capacidade antioxidante da soja e produtos derivados. Science and Food Technology. 2006; 26(4) 921-926.

[19] Jeng TL, Shih YJ, Wu MT, Sung JM. Comparisons of flavonoids and anti-oxidative activities in seed coat, embryonic axis and cotyledon of black soybeans. Food Chemistry. $20101112-1116$.

[20] Qin Y, Jin Xiao-nan, Dong PH. Comparison of Antioxidant Activities in Black Soybean Preparations Fermented with Various Microorganisms. Agricultural Sciences in China. 2010 1065-1071.

[21] Alkema S, Seager SL; The chemical pigments of plants. Journal of Chemical Education. 1982; 59(3) 183. 
[22] Francis FJ. Food Colorants: Anhtocyanins. Critical Reviews in Food Science and Nutrition. 1989 28(4) 273.

[23] Lee J, Durst RW, Wrolstad RE. Determination of total monomeric anthocyanin pigment content of fruit juices, beverages, natural colorants, and wines by the $\mathrm{pH}$ differential method: Collaborative study. Journal AOAC International. 2005; 88(5) 1269-1278.

[24] Levi MAB et al. Three-way chemometric method study and UV-vis absorbance for the study of simultaneous degradation of anthocyanins in flowers of the Hibiscus rosa-sinensys species. Talanta. 2004 62(2) 299-305.

[25] Kahkonen MP, Heinamaki J, Ollilainen V, Heinonen, M. Berry anthocyanins: isolation, identification and antioxidant activities. Journal of the Science of Food and Agriculture. 2003; 83 1403-1411.

[26] Rufino MSM et al. Açaí (Euterpe oleraceae) 'BRS Pará': A tropical fruit source of antioxidant dietary fiber and high antioxidant capacity oil, Food Research International. 2010; doi:10.1016/j.foodres.2010.09.011.

[27] Yeo, S. K.; Ewe, J. A.; Tham, C. S. C.; Liong, M. T. Carriers of Probiotic Microorganisms. In: Probiotics: Biology, Genetics and Health Aspects. LIONG, M.T. Malasia: Springer, 2011; p. 191-215.

[28] Mattila-Sandholm T, Myllarinen P, Crittenden R, Mogensen G, Fonden R, Saarela M. Technological challenges for future probiotic foods. International Dairy Journal. 2002 173-183.

[29] Rivera-Espinoza Y; Gallardo-Navarro Y. Non-dairy probiotic products. Food Microbiology, 2010; 27 1-11.

[30] Ouwehand AC, Svendsen LS, Leyer G. Probiotics: from Strain to Products. In KNEIFEL, Wolfgang, SALMINEN, Seppo. Probiotics and Health Claims. Wiley-Blackell, 2011, p. 37-48.

[31] Sheehan V, Ross P, Fitzgerald GF. Assessing the acid tolerance and the technological robustness of probiotic cultures for fortification in fruit juices. Innovative Food Science and Emerging Technologies, 2007; 8 279-284.

[32] Pereira ALF, Maciel TC, Rodrigues S. Probiotic beverage from cashew apple juice fermented with Lactobacillus casei. Food Research International. 2011; 44 1276-1283.

[33] Yoon KYE, Woodmans EE, Hang YD. Fermentation of tomato juice by lactic acid bacteria. Journal of Microbiology. 2004; 42(4) 315-318.

[34] Yoon KYE, Woodmans EE.; Hang YD. Fermentation of beet juice by beneficial lactic acid bacteria. Lebensmittel-Wissenschaft und-Technologie. 2005; 38 73-75.

[35] Lima IR de. Desenvolvimento de produto vegetal desidratado a base de raízes tuberosas fermentadas com bactérias probióticas protegidas pela presença de betaína. Dis- 
sertação de Mestrado em Ciência de Alimentos, State University of Londrina. Brazil; 2010.

[36] Ellendersen L de SN, Granato D, Guergoletto KB, Wosiacki G. Development and sensory profile of a probiotic beverage from apple fermented with Lactobacillus casei. Engineering in Life Sciences. 2012; 12(4) 1-11.

[37] Baptista EV. Desenvolvimento de ingrediente simbiótico por fermentação de soro de leite e do subproduto da agroindústria de suco de laranja por grãos de Kefir e cultura probiótica. Dissertação de Mestrado em Ciência de Alimentos. State University of Londrina. Brazil; 2010.

[38] Charalampopoulos, D, Wang R, Pandiella SS, Webb C. Application of cereal and cereal components in functional foods: a review. International Journal of Food Microbiology. 2002; 79 131-141.

[39] Charalampopoulos D, Pandiella SS, Webb C. Evaluation of the effect of malt, wheat and barley extracts on the viability of potential probiotic lactic acid bacteria under acidic conditions. International Journal of Food Microbiology. 2003; 82 133-141.

[40] Charalampopoulos D, Pandiella SS. Survival of human derived Lactobacillus plantarum in fermented cereal extracts during refrigerated storage. LWT - Food Science and Technology 2010; 53(3) 431-435.

[41] Rathore S, Salmerón I, Pandiella SS. Production of potentially probiotic beverages using single and mixed cereal substrate fermented with lactic acid bacteria cultures. Food Microbiology. 2012; 30 239-244.

[42] Guergoletto KB, Magnani M, Martin JS; Andrade CG T de J, Garcia S. Survival of Lactobacillus casei (LC-1) adhered to prebiotic vegetal fibers. Innovative Food Science and Emerging Technologies. 2010a; 11 415-4212.

[43] Angelov A, Gotcheva V, Kuncheva R, Hristozova T. Development of a new oat-based probiotic drink. International Journal of Food Microbiology. 2006; 112 75-80.

[44] Bispo E da S, Guimarães AG, Miranda M S. Cacau e café e a aplicação de probióticos e prebióticos. In: Saad SMI, Cruz Adriano, Gomes da; FARIA, José de Assis Fonseca. Probióticos e Prebióticos em Alimentos: Fundamentos e Aplicações Tecnológicas. São Paulo: Editora Varela, 2011. p. 583-598.

[45] Cuenca MM, Quincazán MC. Comparación de la fermentación de bebida de soya e leche de vaca utilizando un cultivo láctico comercial. Ingeniería y competitividad. 2004; 5(2)16-22.

[46] Cruz NS, Capellas M, Jaramillo DP, Trujillo AJ, Guamis B, Ferragut V. Soymilk treated by ultra high-pressure homogenization: Acid coagulation properties and characteristics of a soy-yogurt product. Food Hydrocolloids. 2009; 23(2) 490-496.

[47] Beasley S, Tuorila H, Saris PEJ. Fermented soymilk with a monoculture of Lactococcus lactis. International Journal of Food Microbiology. 2003; 81(2) 159-162. 
[48] Favaro Trindade CS, Terzi SC, Trugo LC, Dello Modesta RC, Couri S. Development and sensory evaluation of soy milk based yoghurt. Archivos Latinoamericanos de Nutrición. 2001; 51(1) 100-104.

[49] Baú TR. Desenvolvimento, caracterização e estabilidade de produto de soja fermentado com cultura de kefir e adição de fibras. Dissertação (Mestrado em Ciência de Alimentos). State University of Londrina. Brazil; 2012.

[50] Fucks RHB, Borsato B, Bona E, Hauly MC. O. Iogurte de soja suplementado com oligofrutose e inulina. Ciência e Tecnologia de Alimentos. 2005; 25(1) 175-181.

[51] De Angelis M, Coda R, Silano M, Minervini F, Rizzello CG, Di Cagno R, Vicentini O, De Vincenzi M, Gobbetti M. Fermentation by selected sourdough lactic acid bacteria to decrease coeliac intolerance to rye flour. Journal of Cereal Science 2006; 43 301314.

[52] Casellas F, et al. Factors impact health-related quality of life in adults with celiac disease: A multicenter study. World Journal of Gastroenterology. 2008; 14(1) 46-52.

[53] Araújo HMC, Araújo WMC, Botelho RBA, et al. Doença celíaca, hábitos e práticas alimentares e qualidade de vida. Revista de Nutrição. 2010; 23(3) 467-474.

[54] Sundar, N.; Crimmins,R.; Swift,G.L. Clinical presentation and incidence of complications in patients with coeliac disease diagnosed by relative screening. Postgraduate Medical Journal. 2007; 83, 273-276.

[55] Abrams S, Griffin I, Hawthorne K, et al. A combination of prebiotic short- and longchain inulin- type fructans enhances calcium absorption and bone mineralization in young adolescents. The American Journal of Clinical Nutrition. 2005; 82(2) 471-476.

[56] Abrams S, Hawthorne K, Aliu O, et al. An inulin-type fructan enhances calcium absorption primarily via an effect on colonic absorption in humans. Journal of Nutrition. 2007; 137(10) 2208-2212.

[57] Capriles Martini LA, Arêas JAG. Metabolic osteopathy in celiac disease: importance of a gluten-free diet. Nutrition Reviews. 2009; 67(10) 599-606.

[58] Dias Capriles V, Gomes Arêas J A. Archivos Latinoamericanos de Nutricion. 2010; 60(3).

[59] Packer SC, Dornhorst A, Frost GS. The glycaemic index of range of gluten-free foods. Diabetic Medicine. 2000; 17(9) 657.

[60] Dukas L, et al. Bowel movement, use of laxatives and risk of colorectal adenomatous polyps among women. United States. Cancer Causes Control. 2000; 11 907-914.

[61] Haque A, Morris ER, Richardson RK. Polysaccharide substitutes for gluten in nonwheat bread. Carbohydrate Polymers. 1994; 25(4) 337-344.

[62] Zandonadi RP. Psyllium como substituto de Glúten. Dissertação (Mestrado em Nutrição Humana) - University of Brasilia. Brazil; 2006. 
[63] Storck CR, Pereira JM, Pereira GW, et al. Características tecnológicas de pães elaborados com farinha de arroz e transglutaminase. Brazilian of Food Journal Technology. II SSA; 2009.

[64] Figueira F da S. Pão sem glúten enriquecido com a microalga Spirulina platensis. Brazilian Journal of Food Technology. 2011; 14(4) 308-316.

[65] Fox RD. Spirulina Production \& Potencial. Aix-en-Provence: Edisud. 1996; 89.

[66] Cohen Z. The chemicals of Spirulina. In: VONSHAK, A. Spirulina Platensis (Arthrospira) Physiology, Cell-Biology and Biotechnology. London: Taylor \& Francis, 1997. $233 \mathrm{p}$.

[67] Colla LM, Reinehr CO, Reichert C, Costa JAV. Production of biomass and nutraceutical compounds by Spirulina platensis under different temperature and nitrogen regimes. Bioresource Technology. Oxford. 2007; 98(7) 1489- 1493.

[68] Morais MG, Miranda MZ, Costa JAV. Biscoitos de chocolate enriquecidos com Spirulina platensis: características físico-químicas, sensoriais e digestibilidade. Food and Nutrition. 2006; 17(3) 323-328.

[69] Berti C, Riso P, Montini LD, Porrini M. In vitro starch digestibility and in vivo glucose response of gluten-free foods and their gluten counterparts. European Journal of Nutrition. 2004; 43 198-204.

[70] Vecchi D, Hamsananda SS. Kefir: "uma benção milagrosa para nosso século". 1999. http://www.angelfire. com/ab6/om/kefir.html (Accessed 13 july 2012).

[71] Silva SMCS, Mura JDPM. Tratado de alimentação, nutrição e dietoterapia. São Paulo: Rocca; 2007. p515-533.

[72] Fasolin LH, Almeida GC, Castanho PS, Netto-Oliveira ER. Chemical, physical and sensorial evaluation of banana meal cookies. Science and Food Technology. 2007; 27(3) 787-792.

[73] Zandonadi RP, Botelho RBA, Gandolfi L, et al. Journal of the Academy of Nutrition and Dietetics. 2012; 112(7) 1068-1072.

[74] Moore MM, Juga B, Schober TJ, et al. Effect of lactic acid bacteria on properties of gluten-free sourdoughs, batters, and quality and ultrastructure of gluten-free bread. Cereal Chemistry. 2007; 84 357-364.

[75] Poutanen K, Flander L, Katina K. Sourdough and cereal fermentation in a nutritional perspective. Food Microbiology. 2009; 26 693-699.

[76] Galle S, Schwab C, Dal Bello F, Coffey A, Ganzle MG, Arendt EK. Influence of in-situ synthesized exopolysaccharides on the quality of gluten-free sorghum sourdough bread. International Journal Food Microbiology. 2012; doi:10.1016/j.ijfoodmicro. 2012.01.009. 
[77] Franco TS, Garcia S, Hirooka EY, Ono ES, dos Santos JS. Lactic acid bacteria in the inhibition of Fusarium graminearum and deoxynivalenol detoxification. Journal of Applied Microbiology. 2011; 111(3) 739-748.

[78] Guergoletto KB, Kuriama F, Kuroda EK, Garcia S, Hirooka EY. Potencial of degradation of microcystins by probiotic bacteria and kefir grains. In: 4th International Congress on Bioprocesses in Food Industries, 2010, Curitiba, Brazil 4th International Congress on Bioprocesses in Food Industries, 2010b.

[79] Morotomi M, Mutai M. In vitro binding of potent mutagenic pyrolyzats to intestinal bacteria. Journal of the National Cancer Institute. 1986; 77 195-201.

[80] Sako T. The world's oldest probiotic: perspectives for health claims. In: Probiotic and health claims. Ed. Kneifel, W \& Salminen, S. Blackwell Publishing Ltd, p.17, 2011.

[81] Chowdhury SR, Basak RK, Sen R, Adhikari B. Optimization, dynamics, and enhanced production of a free radical scavenging extracellular polysaccharide (EPS) from hydrodynamic sediment attached Bacillus megaterium RB-05. Carbohydrate Polymers. 2011; 86, 1327- 1335.

[82] Donot F, Fontana A, Baccou JC, Schorr-Galindo S. Microbial exopolysaccharides: Main examples of synthesis, excretion, genetics and extraction. Carbohydrate Polymers. 2012; 87 951- 962.

[83] Piermaria J, de la CANAL M, Abraham A. Gelling properties of Kefiran, a food grade polysaccharide obtained from kefir grain. Food Hydrocolloids. 2008; 22 1520-1527.

[84] Prasanna PHP, Grandison AS, Charalampopoulos D. Screening human intestinal Bifidobacterium strains for growth, acidification, EPS production and viscosity potential in low-fat milk. International Dairy Journal. 201223 36-44.

[85] Laurenti E. Materiais encapsulantes naturais na obtenção de esferas de S. cerevisiae para incorporação em ração extrusada de frangos de corte. Dissertação de Mestrado em Ciência de Alimentos, Estadual University of Londrina. Brazil, 2011.

[86] Liu J, Luo J, Ye H, Sun Y, Lu Z, Zeng X. Production, characterization and antioxidant activities in vitro of exopolysaccharides from endophytic bacterium Paenibacillus polymyxa EJS-3. Carbohydrate Polymers. 200978 275-281.

[87] Pan D, Mei X. Antioxidant activity of an exopolysaccharide purified from Lactococcus lactis subsp. lactis 12. Carbohydrate Polymers. 2010; 80 908-914.

[88] World Health Organization (2011). New physical activity guidance can help reduce risk of breast, colon cancers: http://www.who.int/mediacentre/news/notes/2011/ world_cancer_day_20110204/en/index.html

[89] Hamilton MT, Hamilton DG, Zderic TW. Role of low energy expenditure and sitting in obesity, metabolic syndrome, type 2 diabetes, and cardiovascular disease. Diabetes. 2007; 56(11) 2655-2667. 
[90] Bhatt DL. Anti-inflammatory agents and antioxidants as a possible "third great wave" in cardiovascular secondary prevention. America Journal of Cardiology. 2008; 101 (10A) 4D-13D.

[91] Flambard B, Johansen E. Developing a functional dairy product: from research on Lactobacillus helveticus to industrial application of Cardi-04 ${ }^{\mathrm{TM}}$ in novel antihypertensive drinking yoghurts. In: Functional Dairy products Vol 2 Ed. Saarela, M. CRC Press, Cambridge, England, 2007, p.506. ISBN 978-1-84569-310-7 (e-book).

[92] Badel S, Bernardi T, Michaud P. New perspectives for Lactobacilli exopolysaccharides. Biotechnology Advances. 2011; 29 54-66.

[93] Rajul J, Rao CV. Diosgenin, a Steroid Saponin Constituent of Yams and Fenugreek: Emerging Evidence for Applications in Medicine. In: BIOACTIVE COMPOUNDS IN PHYTOMEDICINE Ed. Rasooli, I.; Croatia, Intech 2011 p. 127

[94] Hobbs DA, Kaffa N, George TW, Methven L, Lovegrove JA. Blood pressure-lowering effects of beetroot juice and novel beetroot enriched bread products in normotensive male subjects.British Journal of Nutrition, page 1 of 9 doi:10.1017/S0007114512000190.

[95] Webb AJ, Patel N, Loukogeorgakis S, et al. Acute blood pressure lowering, vasoprotective, and antiplatelet properties of dietary nitrate via bioconversion to nitrite. Hypertension. 2008; 51 784-790. 